\title{
PENGARUH MODEL PEMBELAJARAN LIGHTENING THE LEARNING CLIMATE TERHADAP KEMAMPUAN KOMUNIKASI MATEMATIS PESERTA DIDIK
}

\author{
Dwi Andriani ${ }^{1}$, Huri Suhendri ${ }^{2}$, Hawa Liberna ${ }^{3}$ \\ ${ }^{1,2,3,}$ Program Studi Pendidikan Matematika, Universitas Indraprasta PGRI Jakarta \\ Email: andriani.dwi2111@gmail.com
}

\begin{abstract}
Abstrak:
Tujuan penelitian adalah untuk mengetahui adanya pengaruh metode pembelajaran Lightening the Learning Climate terhadap kemampuan komunikasi matematis peserta didik. Metode penelitian yang digunakan Quasi Eksperiment dengan dibagi menjadi dua kelas yaitu kelas eksperimen dengan metode pembelajaran Lightening the Learning Climate dan kelas kontrol dengan metode pembelajaran Ekspositori. Populasi dalam penelitian ini adalah peserta didik SMP Islam Assalamah Depok dan SMP Dwiguna Depok kelas VII Tahun Ajaran 2018/2019. Banyak sampel pada kelas eksperimen dan kelas kontrol masing-masing sebanyak 28 orang. Adapun teknik pengambilan sampel dilakukan secara acak (Simple Random Sampling). Pengukuran dan pengambilan data menggunakan instrument tes tertulis bentuk essay. Sebelumnya soal telah divalidasi selanjutnya dilakukan uji persyaratan analisis data yaitu uji normalitas menggunakan uji Liliefors dan uji homogenitas menggunakan Uji Fisher didapat data kelas kontrol dan kelas eksperimen berdistribusi normal dan bersifat homogen. Berdasarkan uji hipotesis penelitian diperoleh $\mathrm{t}_{\text {hitung }}=2,32>\mathrm{t}_{\text {tabel }}=2,005$ maka $\mathrm{H}_{1}$ diterima dan $\mathrm{H}_{0}$ ditolak. Sehingga dapat disimpulkan bahwa terdapat pengaruh metode pembelajaran Lightening the Learning Climate terhadap kemampuan komunikasi matematis peserta didik.
\end{abstract}

Kata Kunci: Lightening the Learning Climate, Komunikasi Matematis, Peserta Didik

\section{Pendahuluan}

Pada dasarnya kegiatan belajar mengajar di kelas tidak terlepas dari adanya komunikasi, baik itu komunikasi dengan guru maupun komunikasi antara peserta didik dengan peserta didik lainnya. Komunikasi secara umum dapat diartikan sebagai suatu cara untuk menyampaikan suatu pesan dari pembawa pesan ke penerima pesan untuk menginformasikan pendapat atau perilaku baik langsung secara lisan maupun tidak langsung melalui tulisan atau suatu media (Hanif, 2013: 4). Menurut Sumarno (2013: 20) indikator yang menunjukkan kemampuan komunikasi matematika adalah: (1) Menghubungkan benda nyata, gambar, dan diagram ke dalam ide matematika; (2) Menjelaskan ide, situasi dan relasi matematik, secara lisan atau tulisan dengan benda nyata, gambar, grafik dan aljabar; (3)Menyatakan peristiwa sehari-hari dalam bahasa atau simbol matematika; (4) Mendengarkan, berdiskusi, dan menulis tentang matematika; (5) Membaca dengan pemahaman suatu presentasi matematika tertulis.

Selain dalam pembelajaran bahasa, komunikasi juga sangat diperlukan dalam pembelajaran matematika. Menurut Wear dan Indrawati (2017) matematika merupakan bentuk komunikasi yang hampir mendekati kesempurnaan dari segenap bentuk komunikasi yang ada, karena matematika merupakan bahasa yang melambangkan serangkaian makna dari pernyataan yang ingin disampaikan. Komunikasi matematika merupakan salah satu dari lima kemampuan standar yang harus dimiliki siswa dalam belajar matematika yang ditetapkan dalam NCTM (Effendi, 2012) yaitu: kemampuan pemecahan masalah (problem solving), kemampuan penalaran (reasoning), kemampuan komunikasi (communication), kemampuan membuat koneksi (connection), dan kemampuan representasi (representation).

Matematika merupakan bagian dari kurikulum pendidikan dasar, memainkan peranan strategis dalam peningkatan kualitas SDM Indonesia. Namun, kemampuan matematis peserta didik di Indonesia masih berada pada level rendah. Hal ini tercermin dari hasil survei yang dilakukan TIMSS (Trend in International Mathematics and Science 
Study) (Wardhani, 2012: 26) Pada tahun 2015 Indonesia berada pada peringkat 63 dari 70 negara. Hal ini masih jauh dibawah rata-rata skor internasional yaitu 496 sedangkan Indonesia hanya mencapai ratarata skor 371 .

Permasalahan prestasi belajar matematika peserta didik khususnya kemampuan komunikasi matematis peserta didik juga terjadi di SMP Islam Assalamah Depok dan SMP Dwiguna Depok. Berdasarkan hasil nilai UN tiga tahun terakhir (2016 s.d. 2018) terjadi penurunan nilai rata-rata mata pelajaran matematika, seperti pada tabel di bawah ini :

\section{Tabel 1. Ringkasan Hasil Ujian Nasional SMP Islam Assalamah Depok dan SMP Dwiguna Depok}

\begin{tabular}{cccc}
\hline \multirow{2}{*}{ Nama } & \multicolumn{3}{c}{ Rata-rata Nilai UN } \\
Matematika \\
Sekolah & 2018 & 2017 & 2016 \\
\hline $\begin{array}{c}\text { SMP Islam } \\
\text { Assalamah }\end{array}$ & 30.62 & 31.29 & 61.36 \\
Depok & & & \\
SMP & 34.64 & 35.14 & 60.77 \\
Dwiguna \\
Depok
\end{tabular}

(Sumber : Balitbang Kemendikbud, 2019)

Permasalahan tersebut terjadi karena matematika masih dianggap sebagai mata pelajaran yang sulit dan menakutkan, peserta didik masih enggan untuk aktif berkomunikasi dan menyampaikan kekurang pahamannya terhadap materi yang diajarkan oleh guru, peserta didik cenderung pasif, berorientasi pada satu jawaban yang benar, dan aktivitas kelas yang sering dilakukan hanyalah mencatat atau mengerjakan apa yang diperintahkan oleh guru serta kurang tepatnya penggunaan metode pembelajaran yang digunakan oleh guru. Akibatnya, guru tidak mengetahui tingkat kesulitan yang dihadapi oleh masing-masing peserta didik, kemampuan kognitif tingkat tinggi peserta didik sangat lemah karena kegiatan pembelajaran yang biasa dilakukan hanya mendorong peserta didik untuk berpikir pada tataran tingkat rendah serta dapat menurunkan semangat belajar peserta didik karena suasana pembelajaran yang membosankan dan berakibat pada menurunnya prestasi belajar.

Oleh karena itu diperlukan metode pembelajaran yang tepat bagi peserta didik agar dapat belajar secara aktif dan mampu mengasah kemampuan komunikasi matematika tersebut. Salah satunya adalah metode pembelajaran Lightening the LearningClimate (menghidupkan suasana belajar). Menurut Amorie (2015) metode pembelajaran Lightening the Learning Climate adalah metode pembelajaran aktif yang kondusif dalam penerapan metode tersebut diselingi dengan humor-humor yang kreatif yang berkaitan dengan materi pembelajaran yang tengah diajarkan. Adapun langkah-langkah yang dapat diterapkan dalam menggunakan metode pembelajaran Lightening the Learning Climate menurut Cicilya (2014: 17) adalah sebagai berikut :

1) Guru menjelaskan kepada peserta didik ingin melakukan sebuah latihan pembukaan yang menyenangkan dengan peserta didik sebelum serius tentang materi pelajaran.

2) Guru membagi peserta didik dalam bentuk kelompok-kelompok kecil yang heterogen.

3) Guru memberikan materi kepada masing-masing kelompok yang dengan penuh pertimbangan meminta mereka bergembira dengan suatu topik, konsep atau isu penting dalam pelajaran yang guru ajarkan.

4) Guru mengajak setiap kelompok untuk menyampaikan kreasi-kreasi meraka (guru memberikan applaus atas hasilhasil yang disampaikan setiap kelompok).

5) Guru meminta peserta didik untuk memberikan ringkasan dari materi pelajaran yang telah dipelajari.

Berdasarkan uraian masalah ini maka peneliti akan melakukan penelitian pengaruh metode pembelajaran Lightening the Learning Climate terhadap kemampuan komunikasi matematis peserta didik. Penelitian dilakukan pada peserta didik kelas VII SMP di wilayah kecamatan Cipayung kota Depok pada semester genap tahun pelajaran 2018/2019. 


\section{Metode Penelitian}

Metode yang digunakan dalam penelitian ini adalah Quasi Eksperiment. Penelitian ini dibagi menjadi dua kelas yaitu kelas eksperimen dengan metode pembelajaran Lightening the Learning Climate yang diajarkan di kelas VII SMP Islam Assalamah Depok dan kelas kontrol dengan metode pembelajaran Ekspositori yang diajarkan di kelas VII SMP Dwiguna Depok. Desain penelitian adalah sebagai berkut :

$$
\begin{array}{|l|l|}
\hline X_{1} & X \\
\hline Y_{1} & Y_{2} \\
\hline
\end{array}
$$

Gambar 1. Desain Penelitian

Keterangan :

$\mathrm{X}_{1}$ : Metode pembelajaran Lightening the Learning Climate

$\mathrm{X}_{2}$ : Metode pembelajaran Ekspositori

$\mathrm{Y}_{1}$ : Kemampuan komunikasi matematia kelas eksperimen

$\mathrm{Y}_{2}$ : Kemampuan komunikasi matematis kelas kontrol

Penelitian ini dilaksanakan selama Bulan April 2019. Populasi dalam penelitian ini adalah peserta didik SMP Islam Assalamah Depok dan peserta didik SMP Dwiguna Depok kelas VII Tahun Ajaran 2018/2019. Banyak sampel pada kelas eksperimen sebanyak 28 peserta didik dan kelas kontrol sebanyak 28 peserta didik. Adapun teknik pengambilan sampel dilakukan secara acak (Simple Random Sampling). Pengukuran dan pengambilan data kemampuan komunikasi matematis menggunakan instrument tes tertulis bentuk essay yang sebelumnya telah divalidasi dan didapat 8 soal valid dari total 10 soal. Data hasil tes belajar yang telah terkumpul diolah dengan menggunakan statistik yang sesuai. Selanjutnya data diolah dengan uji Liliefors dan uji Fisher untuk menguji kenormalan dan kehomogenan data. Untuk menguji hipotesis dalam penelitian ini diuji dengan menggunakan uji-t. Hipotesis yang digunakan dalam penelituan ini adalah sebagai berikut :

$\mathrm{H}_{0}: \mu_{1} \leq \mu_{2}$ : Kemampuan komunikasi matematika peserta didik pada kelompok pembelajaran yang menggunakan metode Lightening the Learning Climate tidak lebih tinggi atau sama dengan kemampuan komunikasi matematika peserta didik pada kelompok pembelajaran yang menggunakan metode Ekspositori.

$\mathrm{H}_{1}: \mu_{1}>\mu_{2}$ :Kemampuan komunikasi matematika peserta didik pada kelompok pembelajaran yang menggunakan metode Lightening the Learning Climate lebih tinggi daripada kemampuan komunikasi peserta didik pada kelompok pembelajaran yang menggunakan metode Ekspositori.

\section{Hasil dan Pembahasan \\ Hasil \\ Data Kemampuan Komunikasi Matematis}

Dari hasil penelitian yang telah dilaksanakan di SMP Islam Assalamah Depok dan SMP Dwiguna Depok, peneliti telah memperoleh data kelas eksperiemen dan data kelas kontrol, sebagai berikut :

Tabel 2. Skor Frekuensi Kemampuan Komunikasi Matematis (Menggunakan Metode Pembelajaran Lightening the Learning Climate)

\begin{tabular}{|c|c|c|c|c|c|c|c|}
\hline No & Nilai & $\mathrm{F}_{\mathrm{o}}$ & $\mathrm{Xi}$ & $\mathrm{F}_{\mathrm{o}} . \mathrm{Xi}$ & $\mathrm{Xi}-\bar{X}$ & $(\mathrm{Xi}-\bar{X})^{2}$ & $\mathrm{~F}_{0}(\mathrm{Xi}-\bar{X})^{2}$ \\
\hline 1 & $63-68$ & 2 & 65.5 & 131 & -16.9286 & 286.5765 & 573.1531 \\
\hline 2 & $69-74$ & 3 & 71.5 & 214.5 & -10.9286 & 119.4337 & 358.3010 \\
\hline 3 & $75-80$ & 3 & 77.5 & 232.5 & -4.9286 & 24.2908 & 72.8724 \\
\hline 4 & $81-86$ & 12 & 83.5 & 1002 & 1.0714 & 1.1480 & 13.7755 \\
\hline 5 & $87-92$ & 6 & 89.5 & 537 & 7.0714 & 50.0051 & 300.0306 \\
\hline 6 & 93-98 & 2 & 95.5 & 191 & 13.0714 & 170.8622 & 341.7245 \\
\hline \multicolumn{2}{|c|}{ Jumlah } & 28 & & 2308 & & & 1659.857 \\
\hline
\end{tabular}


Tabel 3. Skor Frekuensi Kemampuan Komunikasi Matematis (Menggunakan Metode Pembelajaran Ekspositori)

\begin{tabular}{|c|c|c|c|c|c|c|c|}
\hline No & Nilai & $F_{o}$ & $\mathrm{Xi}$ & $\mathrm{F}_{\mathrm{o}} \cdot \mathrm{Xi}$ & $\mathrm{Xi}-\bar{X}$ & $(\mathrm{Xi}-\bar{X})^{2}$ & $\mathrm{~F}_{0}(\mathrm{Xi}-\bar{X})^{2}$ \\
\hline 1 & $59-64$ & 2 & 61.5 & 123 & -16.0714 & 258.2908 & 516.5816 \\
\hline 2 & $65-70$ & 3 & 67.5 & 202.5 & -10.0714 & 101.4337 & 304.3010 \\
\hline 3 & $71-76$ & 5 & 73.5 & 367.5 & -4.0714 & 16.5765 & 82.8827 \\
\hline 4 & $77-82$ & 12 & 79.5 & 954 & 1.9286 & 3.7194 & 44.6327 \\
\hline 5 & $83-88$ & 4 & 85.5 & 342 & 7.9286 & 62.8622 & 251.4490 \\
\hline 6 & 89-94 & 2 & 91.5 & 183 & 13.9286 & 194.0051 & 388.0102 \\
\hline \multicolumn{2}{|c|}{ Jumlah } & 28 & & 2172 & & & 1587.8571 \\
\hline
\end{tabular}

Tabel 4. Ringkasan Hasil Analisis Statistik Deskriptif

\begin{tabular}{ccc}
\hline Statistik & $\mathrm{K}_{\text {Eksperimen }}$ & $\mathrm{K}_{\text {Kontrol }}$ \\
\hline Mean & 82,429 & 77,571 \\
Median & 83,5 & 77,82 \\
Modus & 84,1 & 79,3 \\
Varian & 61,476 & 58,81 \\
Simpangan Baku & 7,841 & 7,669 \\
\hline
\end{tabular}

Setelah dilakukan uji Normalitas menggunakan uji Liliefors didapat kedua kelompok data berdistribusi normal. Berikut hasil perhitungan uji normalitas :

Tabel 3. Simpulan Uji Normalitas

\begin{tabular}{cccc}
\hline Kelompok Data & $\mathrm{L}_{\text {Hitung }}$ & $\mathrm{L}_{\text {Tabel }}$ & Simpulan \\
\hline Kelompok Eksperimen & 0.1587 & 0.1610 & Normal \\
Kelompok Kontrol & 0.0676 & 0.1610 & Normal \\
\hline
\end{tabular}

Selanjutnya peneliti melakukan uji homogenitas dengan menggunakan uji Fisher dengan hasil perhitungan nilai $\mathrm{f}_{\text {hitung }}$ $=1,045$ dan $\mathrm{f}_{\text {tabel }}=1,88$ pada taraf signifikasi $\alpha=0,05$ dengan derajat kebebasan pembilang $\mathrm{N}_{\mathrm{a}}=28-1=27$ dan derajat kebebasan penyebut $\mathrm{N}_{\mathrm{b}}=28-1=27$.

Oleh karena $\mathrm{f}_{\text {hitung }}=1,045<\mathrm{f}_{\text {tabel }}=1,88$ maka $\mathrm{H}_{0}$ diterima. Sehingga dapat disimpulkan bahwa kedua data memiliki varians homogen. Berikut hasil perhitungan uji homogenitas:

Tabel 4. Simpulan Uji Homogenitas

\begin{tabular}{cccccc}
\hline Data & Jumlah Sampel & Varian & $\mathrm{f}_{\text {Hitung }}$ & $\mathrm{f}_{\text {Tabel }}$ & Simpulan \\
\hline Eksperimen & 28 & 61,47 & \multirow{2}{*}{1,045} & \multirow{2}{*}{1,88} & \multirow{2}{*}{$\mathrm{H}_{0}$ Diterima } \\
Kontrol & 28 & 58,81 & & & \\
\hline
\end{tabular}

Setelah melakukan uji normalitas dan uji homogenitas, peneliti selanjutnya menguji hipotesis dengan menggunakan uji-t dan didapat hasil $t_{\text {hitung }}=2,32$. Berdasarkan tabel distribusi $\mathrm{t}$ untuk taraf signifikasi $\alpha=0,05$ dan $(\mathrm{dk}=28+28-2=54)$ diperoleh $\mathrm{t}_{\text {tabel }}=2,005$ sehingga didapat nilai $t_{\text {hitung }}=2,32>t_{\text {tabel }}=2,005$ maka $\mathrm{H}_{0}$ ditolak dan $\mathrm{H}_{1}$ diterima.

\section{Pembahasan}

Hasil pengujian hipotesis membuktikan bahwa ada perbedaan perolehan kemampuan komunikasi matematis antara peserta didik yang belajar menggunakan metode pembelajaran Lightening the Learning Climate dengan yang belajar menggunakan metode pembelajaran Ekspositori. Berdasarkan hasil penelitian yang relevan diketahui bahwa pengaruh metode pembelajaran 
Lightening the Learning Climate memiliki pengaruh yang baik. Sesuai dengan simpulan Sriharjono (2011) yang menyatakan bahwa penggunaan metode pembelajaran Lightening the Learning Climate dalam pembelajaran matematika dapat meningkatkan kemampuan komunikasi matematika peserta didik. Melalui metode pembelajaran Lightening the Learning Climate peserta didik mengalami iklim pembelajaran yang menyenangkan, antusias, dan tidak membosankan.

Pada penelitian tersebut diketahui bahwa kemampuan komunikasi matematis peserta didik pada kelas VII SMP Islam Assalamah Depok dan kelas VII SMP Dwiguna Depok mencapai kemampuan komunikasi matematis pada kisaran sedang sampai besar. Hal tersebut dibuktikan dari banyaknya peserta didik yang mampu mengerjakan soal essay sebanyak 8 butir soal, dengan nilai rata-rata kelas eksperimen sebesar 82,429 dan rata-rata kelas kontrol sebesar 77,571. Berdasarkan hasil perlakuan, penggunaan metode pembelajaran yang tepat memegang peranan yang sangat penting dalam meningkatkan kemampuan komunikasi matematis peserta didik. Serupa dengan pendapat Wear dan Indrawati (2017) metode pembelajaran sangat besar pengaruhnya dalam penguasaan kemampuan kognitif seseorang. Menurut Wear dan Indrawati (2017) metode pembelajaran yang mengarahkan pada kemampuan komunikasi matematika merupakan proses berpikir kritis dan proses mental untuk mencari dan menemukan jawaban sendiri dalam belajar dapat dilakukan secara individu ataupun kelompok melalui identifikasi, penyelidikan dan penemuan, analisis dan penguatan terhadap hal-hal baru yang ditemukan. Adanya metode pembelajaran yang aktif menjadikan peserta didik mampu menyelesaikan permasalahan matematika dengan baik.

Sesuai dengan penelitian yang telah dilakukan, terbukti bahwa nilai rata-rata hasil kemampuan komunikasi matematis peserta didik yang diajarkan dengan metode pembelajaran Lightening the Learning
Climate lebih tinggi daripada nilai rata-rata kemampuan komunikasi matematis peserta didik yang menggunakan metode pembelajaran Ekspositori. Pada metode pembelajaran Lightening the Learning Climate, peserta didik lebih mudah memahami materi pembelajaran bangun datar segiempat dan segitiga. Hal ini karena peserta didik dapat lebih aktif bertanya dan mengikuti pembelajaran dengan menyenangkan tanpa ada rasa takut terhadap pelajaran matematika, serta lebih percaya diri dalam proses pembelajaran. Lain halnya dengan pembelajaran yang menggunakan metode pembelajaran Ekspositori. Pada metode pembelajaran Ekspositori ini semua pembelajaran terpaku pada guru dan peserta didik cenderung bersifat pasif. Sehingga, peserta didik yang memiliki kemampuan komunikasi matematis tinggi sulit mengajarkan kemampuan yang dimilikinya kepada teman sebayanya.

Berdasarkan pada pengamatan, peningkatan nilai rata-rata pada metode pembelajaran Lightening the Learning Climate juga terjadi karena adanya kelebihan-kelebihan yang dimiliki oleh metode pembelajaran tersebut. Metode pembelajaran Lightening the Learning Climate memiliki kelebihan mampu menciptakan suasana pembelajaran yang menyenangkan sehingga cukup bagus bagi peserta didik untuk memahami isi pembelajaran, mampu meningkatkan rasa percaya diri peserta didik, mampu meningkatkan rasa saling menghargai antar sesama teman, dapat membantu peserta didik menghubungkan masalah matematika kedalam kehidupan nyata, metode ini membantu peserta didik untuk mengembangakan pengetahuan barunya dan bertanggung jawab dalam pelajaran yang mereka lakukan serta mampu meningkatkan keaktifan peserta didik selama proses pembelajaran. Hal ini sesuai dengan pendapat Arsanty (2015) yaitu metode pembelajaran yang dianjurkan saat ini adalah metode yang dapat mengaktifkan peserta didik dalam belajar. Metode pembelajaran Lightening the Learning Climate ini juga mampu mendorong peserta didik melakukan evaluasi sendiri baik 
terhadap hasil maupun proses belajarnya, serta dapat memperlihatkan kepada peserta didik bahwa setiap mata pelajaran pada dasarnya merupakan cara berpikir dan harus dimengerti oleh peserta didik. Metode ini dianggap lebih menyenangkan dan disukai oleh peserta didik, juga dapat mengembangkan kemampuan mereka untuk menyelesaikan dengan pengetahuan baru. Metode ini juga memberikan kesempatan bagi peserta didik untuk mengaplikasikan pengetahuan yang dimiliki dalam dunia nyata, serta mampu mengembangkan minat peserta didik untuk secara terus-menerus belajar.

Berdasarkan dengan hasil penelitian yang telah diuraikan tersebut dapat disimpulkan bahwa adanya pengaruh yang signifikan terhadap kemampuan komunikasi matematis peserta didik yang menggunakan metode pembelajaran Lightening the Learning Climate di kelas VII SMP Islam Assalamah Depok.

\section{Simpulan}

Berdasarkan hasil penelitian ini didapatkan simpulan bahwa terdapat pengaruh metode pembelajaran Lightening the Learning Climate tehadap kemampuan komunikasi matematis peserta didik. Hal ini dapat dilihat dari perhitungan uji-t yaitu nilai $t_{\text {hitug }} 2,32>t_{\text {tsbel }} 2,005$. Hal tersebut menunjukan bahwa nilai rata-rata kemampuan komunikasi matematis peserta didik yang diajarkan dengan metode pembelajaran Lightening the Learning Climate lebih tinggi dibandingkan dengan metode pembelajaran Ekspositori. Penerapan metode pembelajaran Lightening the Learning Climate memiliki pengaruh terhadap kemampuan komunikasi matematis peserta didik di SMP Islam Assalamah Depok dibandingkan dengan menggunakan metode pembelajaran Ekspositori yang diterapkan di SMP Dwiguna Depok.

\section{Daftar Pustaka}

Amorie, Jean. 2015. Peningkatan Hasil Belajar Matematika Siswa Melalui Strategi Pembelajaran Lightening the Learning Climate.
Jurnal Pendidikan Matematika, Vol. 1, No.1. 73-81.

Arsanty, Desy. 2015. Pengaruh Metode Pembelajaran dan Etos Belajar Terhadap Hasil Belajar Matematika Siswa. Jurnal Kajian Pendidikan Matematika, Vol. 1, No. 1. 46-60. DOI: 10.30998/jkpm.v1i1.890

Balitbang Kemdikbud. 2018. Rekap Hasil Ujian Nasional (UN) Tingkat Sekolah.

http://puspendik.kemdikbud.go.id/ hasil-un/

Cicilya, Leny Gestart. 2014. Skripsi. Pengaruh Model Pembelajaran Active Learning Tipe Lightening the Learning Climate untuk Meningkatkan Prestasi Belajar Siswa pada Materi Operasi Hitung Pecahan Dikelas VII SMP Swasta Methodist 1 Rantauprapat T.P 2014/2015. Medan: Universitas HKBP Nommensen.

Effendi, Leo Adhar. 2012. Pembelajaran Matematika Dengan Metode Penemuan Terbimbing Untuk Meningkatkan Kemampuan Representasi Dan Pemecahan Masalah Matematis Siswa Smp.Jurnal Penelitian Pendidikan, Vol. 13, No. 2. 1-10.

Hanif, Muhammad. 2013. Skripsi. Penerapan Model Pembelajaran Collaborative Learning untuk Meningkatkan Kemampuan Komunikasi Matematis Siswa SMA Kelas $X$. Bandung: Universitas Pendidikan Indonesia.

Sriharjono, Nur Aini. (2011). Skripsi. Peningkatan Kemampuan Komunikasi Matematika Siswa Melalui Metode Lightening The Learning Climate (PTK di Kelas VII Semester II SMPN 3 Bulu Tahun Ajaran 2010/2011. 
Surakarta: Universitas Muhammadiyah Surakarta.

Sumarmo, U. 2013. Pendidikan Karakter, Berpikir dan Disposisi Logis, Kritis, dan Kreatif dalam Pembelajaran Matematika. Makalah disajikan dalam perkuliahan Evaluasi Matematika 2011 Pascasarjana UPI. Tidak Diterbitkan.

Wardhani, Sri. 2012. Instrumen Penilaian Hasil Belajar Matematika SMP: Belajar dari PISA dan TIMMS.
Yogyakarta: Kementrian Pendidikan Nasional.

Wear, Ali Sadikin dan Indrawati Renny. (2017). Pengaruh Metode Pembelajaran Inkuiri dan Diskusi pada Materi Pokok Bentuk Aljabar Terhadap Kemampuan Komunikasi dan Kemampuan Pemecahan Masalah Matematika. Jurnal Kajian Pendidikan Matematika, Vol. 2, No. 2. 159171. DOI

10.30998/jkpm.v2i2.2489 